\title{
Improvement of waste water quality by application of mixed algal inocula
}

\author{
M. A. $\operatorname{Riaz}^{1 *}$, B. $\operatorname{Ijaz}^{2}$, A. $\operatorname{Riaz}^{3}$ and M. Amjad ${ }^{4}$ \\ ${ }^{1}$ Department of Environmental Sciences \& Engineering, Government College University Faisalabad, Pakistan \\ ${ }^{2}$ Sustainable Development Study Centre (Environmental Sciences), Government College University Lahore, Pakistan \\ ${ }^{3}$ Department of Zoology, Government College Women University Faisalabad, Pakistan \\ ${ }^{4}$ Department of Botany, Government College University Lahore, Pakistan
}

\begin{abstract}
Present study aim to investigate application of microalgae for improvement of physiochemical parameters of waste water and improvement of treatment process through reducing the pollutant concentrations including coliform bacteria through their ability to uptake nutrients. Aquatic cultures were conducted in container with dimensions of $1.5 \times 3 \mathrm{sq} \mathrm{ft}$. and wastewater samples 5 Litre samples were collected in plastic cans from Sukhnar drain and algal samples were collected from Bhaini Sigyain Village near Ravi Siphon, Lahore. The one experimental treatment lasted for 10 days to make 50\% 5 liter water added concentration and $200 \mathrm{~g}$ of inocula of algae were grown in wastewater container for experiments to optimize at room temperature as local outdoor cultures conditions for wastewater treatment. Total experiment repeated thrice and completed in 30 days. Results show that treatments improved the physiochemical parameter after week. Turbidity (NTU), total suspended solids $(\mathrm{mg} / \mathrm{L})$, total dissolved solids $(\mathrm{mg} / \mathrm{L})$, nitrate $(\mathrm{mg} / \mathrm{L})$, phosphate $(\mathrm{mg} / \mathrm{L})$ decrease $(\mathrm{P}<0.05)$ after treatment. However, $\mathrm{pH}$ not significantly decreases $(\mathrm{P} \geq 0.05)$ pre-treatment values $6.56 \pm 0.05(\mathrm{mg} / \mathrm{L})$ and post-treatment $6.53 \pm$ $0.057(\mathrm{mg} / \mathrm{L})$. Maximum total coliform disinfection $(\mathrm{P}<0.05)$ was indicated with $200 \mathrm{~g}$ of algae was pre-treatment $1602 \pm 6.8(\mathrm{MPN})$ and post treatment $1447 \pm 39.5(\mathrm{MPN})$ observed.
\end{abstract}

Keywords: Algae; Phycoremediation; Physico-chemical parameters; Wastewater; Water quality; Coliform bacteria

\section{Introduction}

Water adversely affected by a wide range of domestic, industrial, commercial or agricultural activities in anthropogenic ways is termed as wastewater and most concerning from an environmental health point of view (Matamoros et al., 2016). Integration of microalgal cultivation system nutrient concentrations and availability vary across the wide range of wastewaters available and considered for the cultivation of algae for sustainable biomass and bio-products, including bio fuels and wastewater remediation (Gupta et al., 2016). Studies revealed that the major cause of water pollution in the form of pathogens and metals contaminants from domestic and industrial other activities is the discharge of sewage without any treatment directly into water bodies like rivers, canals and seas is a destructive deed (Ruin-Marin et al., 2010; Assayed, 2014; Khan et al., 2017).

Mainly the municipal wastewater contains various categories of pathogenic agents including bacteria, helminthes, viruses and several protozoan and fungi. There are a number of harmful diseases and health problems including water borne diseases in the developing nations that can caused by these of pathogens which are frequently occur in municipal wastewater categories in those areas where sanitation is improper or deprived. (Awuah, 2006; Unnithan et al., 2014). There is group of bacteria known as coliform bacteria which are used as indicators for various disease producing pathogens. Water quality can checked for disease causing pathogen of human by the presence coliform bacteria. Coliform bacteria are faecal indicators for microbial contaminations (Abreu-Acosta and Vera, 2010; Brasil et al., 2016). Thermo tolerant coliform bacterial group exist in several environments linking with sewage pollution and Klebsiella spp. originate by degradation in plant in different defensive mechanisms (Schnurr et al., 2015; Matamoros et al., 2015).

In addition, microalgae have an ability to assimilate nutrients from the environment (Pearson et al., 1987; Davies-Colley et al., 1999). In natural and constructed wetlands recently studied bacteria removal by algae-based systems have been studied (Nascimento, 1987; Gabrhelov et al., 1991; Mara et al., 1992; Von Sperling, 2005). Although, there are large number of wastewater treatment techniques and facilities such as adsorption methods, chemical techniques, precipitation, constructed wetlands and other processes are present but the most suitable is biological method because of its least expensiveness for third world countries particularly (Wei, 2008). In areas where there is land, algae based

\footnotetext{
*Corresponding author e-mail: ahsanenv38@gmail.com
} 
wastewater treatment is a better choice (Zhang and Farahbakhsh, 2007). Open ponds and closed photo bioreactors of various designs with algal growth used for wastewater treatment (Oswald, 1995). Algae are vital photosynthetic organisms that can live in different climate conditions such as seawater, freshwater and soil of very hot or cold region environment. Half of the oxygen on earth produces due to algal photosynthesis. Algal growth and development rates are significantly higher compared to that of terrestrial plants significantly (Li et al., 2008; Tabatabaei et al., 2011).

In algae-based system bacterial degradation and processes decay for several factors affecting bacterial elimination involved sunlight exposure, filtration, adsorption and metabolic activity of biofilm, dissolved oxygen concentration, pH (Seidel, 1976; Gopal and Goel, 1993; Vincent et al., 1994; Kadlec and Knight, 1996; Ottov'a et al., 1997; Brix, 1997; Davies-Colley et al., 1999; Graggs et al., 2004; Mayo, 2004; Monfet and Unc, 2017). The objective of the present study is to investigate the role of mix algae inocula in the improvement of physiochemical parameters and reduction of total coliform in urban wastewater.

\section{Materials and methods}

\section{Wastewater Sampling}

Waste water 5 Litre for each container were collected in plastic cans from Sukhnar drain near G. T road Shalimar Garden, Lahore. Tests were performed immediately or the sample was refrigerated (at $4{ }^{\circ} \mathrm{C}$ ) for further analysis. 5 liter distilled water added to make $50 \%$ concentration. Treatments were conducted in plastic container with dimensions of $1.5 \times 3 \mathrm{sq} \mathrm{ft}$.

\section{Algal Sampling}

Algal samples were collected from fresh water pond along River Ravi in Bhaini village near Ravi Siphon, Lahore. The experiment lasted for 10 days $200 \mathrm{~g}$ of inocula of algae were grown in wastewater container for experiments to optimize at room temperature as local outdoor culture conditions for wastewater treatment.

\section{Estimation of growth rate of algea}

The rate of growth of these Inocula of algae species was measured by the estimation of dry weight. These samples were dried in an oven at $80^{\circ} \mathrm{C}$ for 36 hours to calculate its dry weight.

\section{Physical parameter analysis of wastewater}

Samples pH, turbidity (NTU), total suspended solids (mg/L) and total dissolved solids $(\mathrm{mg} / \mathrm{L})$ were determined immediately after sample collection with digital meter as mentioned in APHA (1998) standard methods.

\section{Total coliform estimation}

Total coliform was determined throughout the experiment by MPN/100 method. Culture media was prepared by adding 17.5 $\mathrm{g}$ LT-broth into $500 \mathrm{ml}$ then added distilled water. In pre sterilized test tubes poured $5 \mathrm{ml}$ of culture. To remove contamination of air cotton plugged test tubes covered with standard aluminum foil and autoclaved at $120{ }^{\circ} \mathrm{C}$ for 20 minutes after allow to cooled at room temperature. Cotton plug removed from test and filled with waste water $1 \mathrm{ml}$ test tubes except one blank tube without waste water to compare total coliform MPN/100 after incubation period (APHA, 1998).

\section{Statistical analysis}

The data were analyzed using Graph Pad Prism version 5.00 for Windows, Graph Pad Software, San Diego California USA, and www.graphpad.com. An unpaired t-test is used to compares parameters of waste water to determine which differences are significant.

\section{Result and discussion}

Total experiment repeated thrice and completed in 30 days. Each experimental treatment lasted for 10 days for before and after treatment with $200 \mathrm{~g}$ of algae. Different physiochemical parameter of waste water analyzed were total coliforms (MPN), $\mathrm{pH}$, turbidity (NTU), total suspended solids $(\mathrm{mg} / \mathrm{L})$ and total dissolved solids $(\mathrm{mg} / \mathrm{L})$, phosphate $\left(\mathrm{PO}_{4}\right)^{3-}$ and nitrate $\left(\mathrm{NO}^{3-}\right)$.

Total dissolved solid decrease $(\mathrm{P}<0.05)$ pre-treatment $2186 \pm 18(\mathrm{mg} / \mathrm{L})$ and post-treatment 12.34 $\pm 16.37(\mathrm{mg} / \mathrm{L})$. Total suspended solids results in pre-treatment $652.7 \pm 11.85$ $(\mathrm{mg} / \mathrm{L})$ and post-treatment $607.7 \pm 16.44(\mathrm{mg} / \mathrm{L})$. Similarly $\mathrm{pH}$ not significantly decease pre-treatment $6.56 \pm 0.05(\mathrm{mg} / \mathrm{L})$ and post-treatment $6.53 \pm 0.057(\mathrm{mg} / \mathrm{L})$ and turbidity pre-treatment $68.33 \pm 1.528$ (NTU) and post treatment $54.67 \pm 1.5$ (NTU). Maximum total coliform reduction was indicated with $150 \mathrm{~g}$ of algae was found to be most favorable option. Reduction in total coliforms observed pre-treatment $1602 \pm 6.8(\mathrm{MPN})$ and post treatment $1447 \pm 39.5$ (MPN). Present study revealed that algae for wastewater treatment are very effective for reduction of coliform bacteria along with other various parameters from municipal wastewater.

For more than half a century urban waste treatment has been a significant subject of attention in microalga research (Beuckels et al., 2015). However the treatments complexity due to nutrient enrichment of waterbodies is a nuisance for safe water supply and potential microalga research. Use of algal based systems application increased over the past few decades for better environmental management (Khan et al., 2017). Excessive and rapid development of algae as consequently negative impact on of aquatic life and but zero 
Table I. Comparison of physiochemical parameter of samples pre and Post treatments (A) Total coliforms (MPN), (B) Turbidity, (C) Total suspended solids, (D) Total Dissolved Solids, (E) pH , (F) Phosphate $\left(\mathrm{PO}_{4}\right)^{3-}(\mathrm{G})$ Nitrate $(\mathrm{NO})^{3-}$

\begin{tabular}{|c|c|c|c|c|c|c|c|c|}
\hline & $\begin{array}{l}\text { Coliforms } \\
\text { (MPN) }\end{array}$ & $\begin{array}{l}\text { Turbidity } \\
\text { (NTU) }\end{array}$ & $\begin{array}{l}\text { Total } \\
\text { suspended } \\
\text { solids (mg/L) }\end{array}$ & $\begin{array}{l}\text { Total dissolved } \\
\text { solids }(\mathrm{mg} / \mathrm{L})\end{array}$ & $\mathrm{pH}$ & & $(\mathrm{mg} / \mathrm{L})$ & $(\mathrm{mg} / \mathrm{L})$ \\
\hline $\begin{array}{r}\text { Pre -treatment } \\
(\text { Mean } \pm \text { SD })\end{array}$ & $1602 \pm 6.8$ & $68.33 \pm 1.528$ & $652.7 \pm 11.85$ & $2186 \pm 1883$ & $\begin{array}{l}6.567 \\
0.033 \\
\end{array}$ & \pm & $\begin{array}{l}1.900 \pm \\
0.1000\end{array}$ & $\begin{array}{l}8.333 \pm \\
0.5774\end{array}$ \\
\hline $\begin{array}{l}\text { Post-treatment } \\
(\text { Mean } \pm \text { SD })\end{array}$ & $1447 \pm 39.5$ & $54.67 \pm 1.528$ & $607.7 \pm 16.44$ & $12.34 \pm 16.37$ & $\begin{array}{l}6.533 \\
0.033 \\
\end{array}$ & \pm & $\begin{array}{l}1.665 \pm \\
0.06\end{array}$ & $\begin{array}{l}6.665 \pm \\
0.5994 \\
\end{array}$ \\
\hline $\mathrm{P}$ value & 0.0026 & 0.0004 & 0.0184 & $<0.0001$ & 0.5185 & & 0.0239 & 0.0240 \\
\hline $\begin{array}{l}\mathrm{P} \text { value } \\
\text { summary }\end{array}$ & $* *$ & $* * *$ & $*$ & $* * *$ & ns & & $*$ & $*$ \\
\hline $\begin{array}{l}\text { Are means } \\
\text { signif. different? } \\
(\mathrm{P}<0.05)\end{array}$ & Yes & Yes & Yes & Yes & No & & Yes & Yes \\
\hline
\end{tabular}

death beneficial consequences by limited algal presence (Wang et al., 2009; Unnithan et al., 2014; Assayed et al., 2014).

Mixed microalgae culture for waste water nutritional contents related with removal of nitrate and phosphate because these nutrients of levels positively affect the growth of algae species (Fried et al., 2012; Ruiz-Martinez et al., 2014) and The use of immobilized microalgae in waste water processing is very adequate and offers significant advantages (Wang and Lan., 2011; Arashiro., 2015; Krustok et al., 2016). Nutrients total suspended solids and total dissolved solid particles and oxygen concentration improved due to the active photosynthesis consumption taking place in the containers with a high concentration of photosynthetic of microalgae (Doucha and Lívanský, 2006).

The efficacy of algae on the removal of faecal bacteria in free water surface (FWS) wetlands and wastewater treatment facilities and are past two decades well documented in different research studies (Curtis, 1990; Curtis et al., 1992; Van der Steen et al., 2000; Garcia et al., 2008; Valigore et al., 2012). Bacteria in the pound aquatic environment attaches to solid surfaces by secreting consents of extracellular polysaccharides as its attachment properties (Sanin et al., 2003; Awuah, 2006).

Total coliform reductions of $90-99 \%$ have been investigated in submerged surface flow systems depending on the involved sunlight exposure, hydraulic retention time and species of macrophytes applied (Moshiri, 1993; Karathanasis et al., 2003; Vymazal, 2005), However, a higher bacteria removal has been observed in previous experiences with Scirpuslacustris planted in submerged surface flow wetlands total califormabout $99.999 \%$. Removal efficiency (>99.9\%) for fecal coliform in effluents of submerged surface system combined with other treatment like waste stabilization ponds, vertical flow wetlands (Ansola et al., 2003; Kimwaga et al., 2004; Keffala and Ghrabi, 2005).

\section{Conclusion}

Present study revealed that algae for wastewater treatment are very effective for reduction of coliform bacteria along with other various parameters from municipal wastewater. The results showed that algae for wastewater treatment experiment lasted for 10 days after treatment reduction total coliforms (MPN), turbidity (NTU), total suspended solids $(\mathrm{mg} / \mathrm{L})$ and total dissolved solids $(\mathrm{mg} / \mathrm{L})$ concentrations were increasing. Phosphate $\left(\mathrm{PO}_{4}\right)^{3-}$, Nitrate $(\mathrm{NO})^{3-}$ activity was decreasing that indicated with mix algae inocula was found to be most favorable and very active coliform bacteria disinfection performance in urban wastewater along with other various parameters from municipal wastewater to reduced health risk in poor sanitation areas. Wastewater treatment system by algal based proved cost-effectiveness system and effective alternative and improvement to the conventional wastewater treatment facilities to bring waste water pollutants into their permissible limits in developing countries.

\section{References}

Abreu-Acosta N and L Vera (2010), Occurrence and removal of parasites, enteric bacteria and faecal contamination indicators in wastewater natural reclamation systems in Tenerife- Canary Islands, Spain, Ecol. Eng. 37: 496503.

Ansola G, Gonz' alez JM, Cortijo Rde and Luis E (2003), Experimental and full-scale pilot plant constructed wetlands for municipal wastewater treatment, Ecol. Eng. 21, 43-52.

APHA (1998), Standard Methods for the Examination of Water and Wastewater, 20 ${ }^{\text {th }}$ Ed., American Public Health Association, American Water Works Association, Water Pollution Control Federation, Washington, DC, USA . 
Arashiro LT (2015), Algal-bacterial consortia for nitrogen removal from wastewater: Experimental and modeling studies (Doctoral dissertation, Ghent University, Belgium).

Assayed A, Chenoweth J and Pedley S (2014), Drawer compacted sand filter: a new and innovative method for on-site grey water treatment, Enviroltechnol 35(19): 2435-2446.

Awuah E (2006), Pathogen removal mechanisms in waste stabilisation ponds, $P h D$ Thesis, Wageningen University/UNESCO-IHE Institute for Water Education, The Netherlands.

Beuckels A, Smolders E and Muylaert K (2015), Nitrogen availability influences phosphorus removal in microalgae-based wastewater treatment, Water Res. 77: 98-106.

Brasil BSAF, Silva FCP and Siqueira FG (2016), Microalgae biorefineries: The Brazilian scenario in perspective, New Biotechnol. 16: 4-9.

Brix H (1997), Do macrophytes play a role in constructed treatment wetlands? Water Sci. Technol. 35 (5): 11-17.

Curtis TP (1990), Mechanisms for the removal of faecal coliforms from waste stabilization ponds, $P h D$ Thesis, University of Leeds, Leeds, United Kingdom.

Curtis TP, Mara DD and Silva SA (1992), Influence of pH, oxygen and humic substances on ability of sunlight to damage faecal coliforms in waste stabilization pond water, Appl. Environ. Microbiol 58: 1335-1343.

Davies-Colley RJ, Donnison AM, Speed DJ, Ross CM and Nagels JW (1999), Inactivation of fecal indicator microorganisms in waste stabilization ponds: interactions of environmental factors with sunlight, Waste Res. 33(5): 1220-1230.

Dewedar H and Bahgat M (1995), Fate of faecal coliform bacteria in a wastewater retention reservoir containing Lemnagibba L., Water Res. 29: 2598- 2600.

Doucha J and Lívanský K (2006), Productivity, $\mathrm{CO}_{2} / \mathrm{O}_{2}$ exchange and hydraulics in outdoor open high density microalgal (Chlorella sp.) photobioreactors operated in a Middle and Southern European climate, J. Appl. Phycol. 18: 811-826.

Fried S, Mackie B and Nothwehr E (2012), Nitrate and phosphate levels positively affect the growth of algae species found in Perry Pond, Tillers 4: 21-24.
Gabrhelova M (1991), Quality of water in the stabilization system from the point of view of human medicine, CLEAN-Soil, Air, Water 19(5): 545-555.

Garcia M, Soto F, Gonzalez JM and Becares E (2008), A comparison of bacterial removal efficiencies in constructed wetlands and algae-based systems, Ecol. Eng. 32(3): 238-243.

Gopal By and Goel U (1993), Competition and allelophaty in aquatic plants communities, Bot. Rev. 59: 155-210.

Graggs R, Zwart A, Nagels J and Davies-Colley W (2004), Modelling sunlight disinfection in a high rate pond, Ecol. Eng. 22: 113-122.

Gupta PL, Lee SM and Choi HJ (2016), Integration of microalgal cultivation system for wastewater remediation and sustainable biomass production, World J. Microbiol and Biotechnol 32(8): 1-11.

Kadlec RH and Knight RL (1996), Treatment Wetlands, Lewis Publishers, CRC Press, Boca Raton, FL, USA.

Karathanasis AD, Potter CL and Coyne MS (2003), Vegetation effects on fecal bacteria, BOD, and suspended solid removal in constructed wetlands treating domestic wastewater, Ecol. Eng. 20: 157-169.

Keffala C and Ghrabi A (2005), Nitrogen and bacterial removal in constructed wetlands treating domestic wastewater, Desalination 185(1-3): 385-389.

Khan MZ, Nizami AS, Rehan M, Ouda OKM, Sultana S, Ismail I M and Shahzad K (2017), Microbial electrolysis cells for hydrogen production and urban wastewater treatment: A case study of Saudi Arabia, Applied Energy 185: 410-420.

Kimwaga RJ, Mashauri DA, Mbwette TSA, Katima JHY and Jorgensen SE (2004), Use of coupled dynamic roughing filters and subsurface horizontal flow constructed wetland system as appropriate technology for upgrading the waste stabilization ponds effluents in Tanzania, Phys. Chem. Earth 29: 1243-1251.

Krustok I, Odlare M, Truu J and Nehrenheim E (2016), Inhibition of nitrification in municipal wastewater-treating photobioreactors: Effect on algal growth and nutrient uptake, Bioresource technology 202: 238-243. 
Li Y, Horsman M, Wu N, Lan CQ and Dubois-Calero N (2008). Biofuels from microalgae, Biotechnology progress 24(4): 815-820.

Mara DD, Mills SW, Pearson HW and Alabaster GP (1992), Waste stabilization ponds: a viable alternative for small community treatment systems, Water and Environment Journal 6(3): 72-78.

Matamoros V, Gutiérrez R, Ferrer I, García J and Bayona JM (2015), Capability of microalgae-based wastewater treatment systems to remove emerging organic contaminants: a pilot-scale study, J. hazardous materials 288: 34-42.

Matamoros V, Uggetti E, García J and Bayona JM (2016), Assessment of the mechanisms involved in the removal of emerging contaminants by microalgae from wastewater: a laboratory scale study, J. hazardous materials 301: 197-205.

Mayo AW (2004), Kinetics of bacterial mortality in granular bed wetlands, Phys. Chem. Earth 29: 1259-1264.

Monfet E and Unc A (2017), Defining wastewaters used for cultivation of algae, Algal Research 24: 520-526.

Moshiri GA (1993), Constructed Wetland for Water Quality Improvement, CRC Press.

Nascimento MJ (1987), Microorganisms removal in waste stabilization ponds in Portugal, Water Sci. Technol. 19: 141-144.

Oswald WJ (1995), Ponds in the twenty-first century, Water Science and Technology 31(12): 1-8.

Ottova V, Balcarova J and Vymazal J (1997), Microbial characteristics of constructed wetlands, Water Sci. Technol. 30 (5): 117-124.

Pearson HW, Marcon A and Melo H (2011), The removal of thermo-tolerant coliform bacteria by immbilized waste satbilization pond algae, Water Scince and Technology 63(6): 1075-1080.

Pearson HW, Mara DD, Mills SW and Smallman DJ (1987), Physicochemical parameters influencing faecal bacterial survival in waste stabilization ponds, Water Sci. Technol. 19: 145-152.

Ruin-Marin A LG, Mendoza-Espinosa and Stephenson T (2010), Growth and nutrient removal in free and immobilized green algae in batch and semicontinuous cultures treating real wastewater, Bioresource Technology 101(1): 58- 64.

Ruiz-Martinez A, Serralta J, Pachés M, Seco A and Ferrer J (2014), Mixed microalgae culture for ammonium removal in the absence of phosphorus: Effect of phosphorus supplementation and process modeling, Process Biochem. 49(12): 2249-2257.

Sanin SL, Sanin FD and Bryers JD (2003), Effect of starvation on the adhesive properties of xenobiotic degrading bacteria, Process Biochem. 38: 909-914.

Schnurr PJ and Allen DG (2015), Factors affecting algae biofilm growth and lipid production: A review, Renewable and Sustainable Energy Reviews 52: 418-429.

Seidel K (1976), Macrophytes and water purification In: Biological Control of Water Pollution Control, Ed., Tourbier J and Pierson RW University of Pennsylvania Press, Philadelphia.

Tabatabaei M, Tohidfar M, Jouzani GS, Safarnejad M and Pazouki M (2011), Biodiesel production from genetically engineered microalgae: future of bioenergy in Iran, Renewable and Sustainable Energy Reviews 15(4): 1918-1927.

Unnithan VV, Unc A and Smith GB (2014), Mini-review: a priori considerations for bacteria-algae interactions in algal biofuel systems receiving municipal wastewaters, Algal Research 4: 35-40.

Valigore JM, Gostomski PA, Wareham DG and O'Sullivan, AD (2012), Effects of hydraulic and solids retention times on productivity and settleability of microbial (microalgal-bacterial) biomass grown on primary treated wastewater as a biofuel feedstock, Water Research 2957-2964.

Van Buuren JCL and Hobma S (1991), The faecal coliform removal rate at post treatment of anaerobically pre-treated domestic wastewater, Department of Environ. Tech., Agricultural University, Wageningen.

Van der Steen P, Brenner A, Shabtai Y and Oron G (2000a), The effect of environmental conditions on faecal coliform decay in post-treatment of UASB reactor effluent, Water Sci. Technol. 42, 111-118.

Van der Steen P, Brenner A, Shabtai Y and Oron G (2000b), Improved faecal coliform decay in integrated 
duckweed and algal ponds, Water Sci. Technol. 42: 363-370.

Vincent G, Dallaire S and Lauzer D (1994), Antimicrobial properties of roots exudate of three macrophytes: Menthaaquatica L., Phragmitesaustralis (Cav.) Trin. and Scirpuslacustris L. In: Fourth International Conference on wetland Systems for Water Pollution Control, 6-10.

Von Sperling M (2005), Modelling of coliform removal in 186 facultative and maturation ponds around the world, Water Res. 39(20): 5261-5273.

Vymazal J (2005), Horizontal sub-surface flow and hybrid constructed wetlands systems for wastewater treatment, Ecol. Eng. 25(5): 478-490.

Wang B and Lan CQ (2011), Biomass production and nitrogen and phosphorus removal by the green alga Neochlorisoleoabundans in simulated wastewater and secondary municipal wastewater effluent, Bioresource technology 102(10): 5639-5644.

Wang D and Fiessel W (2008), Evaluation of media for simultaneous enumeration of total coliform and
Escherichia coli in drinking water supplies by membrane filtration techniques, J. Environ. Sci. 20: 273-277.

Wang GX, Zhang LM, Chua H, Li XD, Xia MF and Pu PM (2009), A mosaic community of macrophytes for the ecological remediation of eutrophic shallow lakes, Ecol.Eng. 35(4): 582-590.

Wei X, Viadero Jr RC and Bhojappa S (2008), Phosphorus removal by acid mine drainage sludge treatment plants, Water Research 42: 3275-3284.

Zhang K and Farahbakhsh K (2007), Removal of native coliphages and coliform bacteria from municipal wastewater by various wastewater treatment processes: Implications to water reuse, Water Research 41: $2816-2824$. 